\title{
A tényleges párolgás és a talaj vízkészlet becslése tenyészidőszakban
}

\author{
${ }^{1}$ ÁCS FERENC, ${ }^{1}$ BREUER HAJNALKA és ${ }^{2}$ SZÁSZ GÁBOR \\ ${ }^{1}$ ELTE Meteorológiai Tanszék, Budapest és \\ ${ }^{2}$ Debreceni Egyetem, Agrometeorológiai Obszervatórium, Debrecen
}

\section{Bevezetés}

A tényleges párolgás (ET) - ami a szárazföldön a csupasz talaj párolgása és a növényi párolgás összege - a hidrológiai ciklus egyik legfontosabb eleme. Az ET egyaránt függ a légkör, a talaj és a növényzet tényezöitől, ezért területi változatossága igen nagy. Mivel az ET mérése komplex feladat és költségigényes módszereket igényel (szemben, pl. a csapadék mérésével), e területi változatosság feltérképezése operatív jellegü mérések keretében kivitelezhetetlen feladat mind technikai, mind gazdasági szempontból. Így az ET tér- és időbeli változásainak becslését modellek alapján végezzük.

A tényleges párolgás becslésére három modelltípus ismert:

1. Modellek, melyek a tényleges párolgást a potenciális párolgás (PET) alapján becsülik az ún. $\beta$ függvény számításával. E módszert föleg a növényi párolgás becslésére használták (pl. MiNTZ \& WALKER, 1993). Manapság már kevésbé használatosak.

2. Modellek, melyek a párolgást a párolgó felszín vízellátottságának és a párolgó felszín feletti levegő párologtató képességének függvényében becsülik. A becsült párolgás a két számított párolgás közül mindig a kisebb értékkel rendelkező párolgással egyenlő. Ha növényi párolgásról van szó, a vízellátottság függvényében alakuló gyökérzet vízfelvétele egyaránt függ a növényzet biológiai és a talaj fizikai tulajdonságaitól (MONTEITH, 1995).

3. Modellek, melyek a párolgást a csupasz talaj és/vagy a növényállomány párolgásával szemben kifejtett felszíni ellenálás becslése alapján értékelik (MONTEITH, 1965). E felszíni ellenállás nagymértékben függ a párolgó felszín vízellátottságától és a felszínre jutó besugárzástól (ÁCS et al., 2005). A párolgó felszín vízellátottsága viszont nagymértékben függ a talaj hidrofizikai tulajdonságaitól. Manapság e modellek a legelterjedtebbek.

A 2. és a 3. modelltípus számos adatot tartalmaz, amelyek (főleg hosszú távon) nem mindenhol és nem feltétlenül állnak rendelkezésre. Ezért az 1. csoportba tartozó modelleket gyakran alkalmazták (STONE et al., 1977; POSZA \& STOLLÁR, 1983;

Postai cím: ÁCS FERENC, ELTE Meteorológiai Tanszék, 1117 Budapest, Pázmány Péter sétány1/a.E-mail: acs@caesar.elte.hu 
SZÁSZ, 1988; MINTZ \& WALKER 1993; MOCKO \& SUD, 1998). A $\beta$ parametrizálásán túl e modellek közös tulajdonsága, hogy a talajnedvesség-tartalom elöre jelzésére az ún. „kanna-modellt” alkalmazzák (MANABE, 1969).

Hazánkban a párolgás és az aktuális talaj vízkészlet ismerete a mezőgazdasági tevékenység miatt mindig fontos feladat volt. Hazánkban erre a THORNTHWAITE (1948) módszer honosodott meg. A módszert BERÉNYI (1943), majd KAKAS (1960) és SZESZTAY (1958) is alkalmazta. SZESZTAY (1958) hidrológiai szempontból szemlélte a módszert és alkalmazásai kisebb vízgyüjtőkre vonatkoztak. Megemlítendő SZEPESINÉ (1966) Kárpát-medencére vonatkozó tanulmánya is, amely egyes meteorológiai állomások energiaháztartását is vizsgálta. Számításaikban a talaj hasznos vízkészlete egységesen $300 \mathrm{~mm}$ volt. Thornthwaite módszerét SzÁsz (1963) is alkalmazta. Vizsgálataiban néhány állomás vízháztartási összetevőinek és hasznos vízkészletének kapcsolatát elemezte. E tanulmányok a talaj vízháztartási tulajdonságainak területi változatosságát nem vették számításba, és nem is elemezték a talajnak a párolgásra gyakorolt hatását.

Jelen munka módosított Thornthwaite-féle modellt mutat be, amely számításba veszi a talaj párolgásra gyakorolt hatását. Thornthwaite eredeti modelljét két vonatkozásban módosítottuk:

1. A potenciális párolgás mellett a tényleges párolgást is számítottuk, és

2. a talaj hasznos vízkészlete nagyságának számításában a fizikai féleséget is figyelembe vettük.

Az első módosítással megváltoztattuk az eredeti Thornthwaite-féle parametrizációt (pl. a víztöbblet parametrizálása), és növeltük a modell mezoskálájú alkalmazhatóságát. A második módosítással számításba vesszük a talaj fizikai félesége területi eloszlásának párolgásra gyakorolt hatását. Modellalkalmazásaink során foglalkozunk:

- a hazai adatállományon végzett verifikációs vizsgálatokkal;

- a párolgás, a talaj vízkészlet és a környezeti tényezők [csapadék $(\mathrm{P})$, hőmérséklet $(\mathrm{T})]$ közötti kapcsolat statisztikai elemzésével; és

- a párolgás és a talaj vízkészlet területi és időbeli változásainak elemzésével.

\section{Anyag és módszer}

\section{A módositott Thornthwaite-féle modell}

A módosított Thornthwaite-féle modellben a talaj vízkészlet becslésére kanna típusú modellt, míg a párolgás parametrizálására a $\beta$ függvény számításán alapuló módszert használjuk. A modell bemenő adatait klimatológiai- és talajadatok alkotják. A klimatológiai adatokat havi csapadék és léghőmérsékleti adatok, míg a talajadatokat az adott talaj fizikai féleségnek megfelelő szabadföldi vízkapacitáshoz $\left(\mathrm{VK}_{\mathrm{sz}}\right)$ és a hervadásponthoz $\left(\mathrm{VK}_{\mathrm{h}}\right)$ tartozó talaj vízkészlet értékek, valamint a talaj vízkészlet kezdeti értéke alkotják. A modell kimenő adatai: a tényleges (ET) és a potenciális (PET) párolgás, a talaj vízkészlet (VK), a víztöbblet (S) és a Thornthwaite-féle klímaképlet. 
A modellben a talajszelvény és a gyökérzóna mélysége $1 \mathrm{~m}$. Ez nyilván durva megközelítés, de e tanulmányban nem vettük számításba a gyökérzóna mélységének területi változatosságát. Ezért a gyökérzóna mélységére a leggyakrabban használt $1 \mathrm{~m}$-es értéket vettük. A modellben számított ET-t a $\beta$ függvény parametrizálása határozza meg. MINTZ és WALKER (1993) gyepre vonatkozó parametrizációját alkalmaztuk. A modell nem tesz különbséget a csupasz talaj és a növényzet között. A modell számításba veszi a talaj öt fö fizikai félesége közötti különbségeket, de nem tesz különbséget a szikes és a nem szikes talajok között. A modell a téli évszak folyamatait sem szimulálja, azaz nem becsüli a hótakaró és/vagy a talajjég olvadását, valamint a talajnedvesség megfagyását. A víztöbblet parametrizálásánál nem veszi számításba sem a domborzati viszonyokat, sem a talajvíz mélységét. A modell a keletkező víztöbblet lefolyásával kapcsolatban sem ad információt.

Mindezek ellenére a modell használata előrelépést jelent a korábbi Thornthwaite-féle modellekhez képest, mivel lehetővé teszi a tényleges párolgás és a talajkarakterisztikák közötti kapcsolatok mezoklimatológiai becslését és elemzését.

\section{A párolgás és a talaj vizkészlet számitása}

Az ET-t a $\beta$ függvény alapján becsüljük,

$$
E T=\beta \cdot P E T,
$$

ahol: $\beta$ az ET és a PET aránya.

A PET parametrizációk közül a Thornthwaite-féle (THORNTHWAITE, 1948) parametrizáció a legismertebb.

THORNTHWAITE (1948) parametrizációja. - THORNTHWAITE (1948) a PET értékét a hömérséklet és a potenciális napfénytartam alapján becsülte. A PET egyenletét az Egyesült Államokban végzett liziméteres mérések alapján szerkesztette meg. Az egyenletben nem szerepel az advekció hatása és az albedo állandó. A PET módosítása MCKENNEY és ROSENBERG (1993) nevéhez füződik. Ez alapján

$$
\text { PET }=1,6 \cdot\left(\frac{L}{12}\right) \cdot\left(\frac{N}{30}\right) \cdot\left(\frac{10 T}{I}\right)^{a},
$$

ahol: L a nappalok hosszának havi átlaga (óra), $\mathrm{N}$ a hónap napjainak száma és $\mathrm{T}$ a havi átlaghőmérséklet $\left({ }^{\circ} \mathrm{C}\right)$, a PET dimenziója $\mathrm{mm} \cdot$ hónap $^{-1}$, I pedig a hőindex:

$$
\begin{gathered}
I=\sum_{j=1}^{12}\left(\frac{T}{5}\right)^{1,514} \\
a=6,75 \cdot 10^{-7} \cdot I^{3}-7,71 \cdot 10^{-5} \cdot I^{2}+1,792 \cdot 10^{-2} \cdot I+0,49239 .
\end{gathered}
$$

A $\beta$ függvény parametrizálása. - MINTZ and WALKER (1993) gyep felett végzett mérései alapján:

$$
\beta=1-\exp \left(-6,8 \cdot \frac{V K-V K_{h}}{V K_{s z}-V K_{h}}\right),
$$


ahol: $\quad \mathrm{VK}$ az aktuális talaj vízkészlet $\left(\mathrm{mm} \cdot \mathrm{m}^{-1}\right), \mathrm{VK}_{\mathrm{h}}$ a hervadásponthoz tartozó, $\mathrm{VK}_{\mathrm{sz}} \mathrm{a}$ szabadföldi vízkapacitáshoz tartozó talaj vízkészlet $\left(\mathrm{mm} \cdot \mathrm{m}^{-1}\right)$. Látható, hogy a $\beta$ és a VK közötti kapcsolat kifejezetten nemlineáris a kitevőben szereplő 6,8-es nagyságú együttható miatt.

A talaj vízkészlet számítása. - A talaj vízkészletet numerikusan a következő formula alapján számítjuk:

$$
V K_{t+1}=V K_{t}+\frac{F\left(V K_{t}\right)}{1-\left.\frac{1}{2} \cdot \frac{\partial F}{\partial V K}\right|_{t} \cdot \Delta t},
$$

ahol: az $\mathrm{F}(\mathrm{VK})$ függvény az $\mathrm{F}(\mathrm{VK})=\mathrm{P}-\mathrm{ET}(\mathrm{VK})-\mathrm{S}(\mathrm{VK})$ alakban írható fel. A $\Delta$ t időlépték, esetünkben, 1 hónap. Januárban mindig Euler explicit sémát használunk, a végső $\mathrm{VK}_{\mathrm{t}} \mathrm{t}$ pedig a $\mathrm{VK}_{\mathrm{t}+1}$ és a $\mathrm{VK}_{\mathrm{t}}$ átlagolásával becsültük. Bármilyen sémát is alkalmazunk, a $\mathrm{VK}$ kezdeti értéke ismeretlen. Javasolandó, hogy a VK kezdeti értéke a valóságot leginkább megközelítő legyen. A feltétel teljesülésekor a számítás ideje rövidebb.

\section{Adatok}

Éghajlati adatok. - Az éghajlati adatokat Magyarország 115 klímaállomásának P-T (csapadék-hőmérséklet) adatai alkotják, amelyek az 1901-től 1950-ig terjedő időszakra vonatkoznak (KAKAS, 1960). E csapadék- és hőmérsékleti mezők csupán kismértékben térnek el a legújabb csapadék- és hőmérsékleti mezőktől (Magyarország Klíma Atlasza, 2000). Az állomások P-T diagramja az 1. ábrán látható.

Talajadatok. - Talajjellemzőként a szabadföldi vízkapacitás és a hervadáspont értékeit használtuk. A $\mathrm{VK}_{\mathrm{h}}$ és $\mathrm{VK}_{\mathrm{sz}}$ értékek a talaj fizikai féleségétől és a meghatározási módjuktól függenek. Öt fizikai talajféleséget különböztetünk meg: a homo-

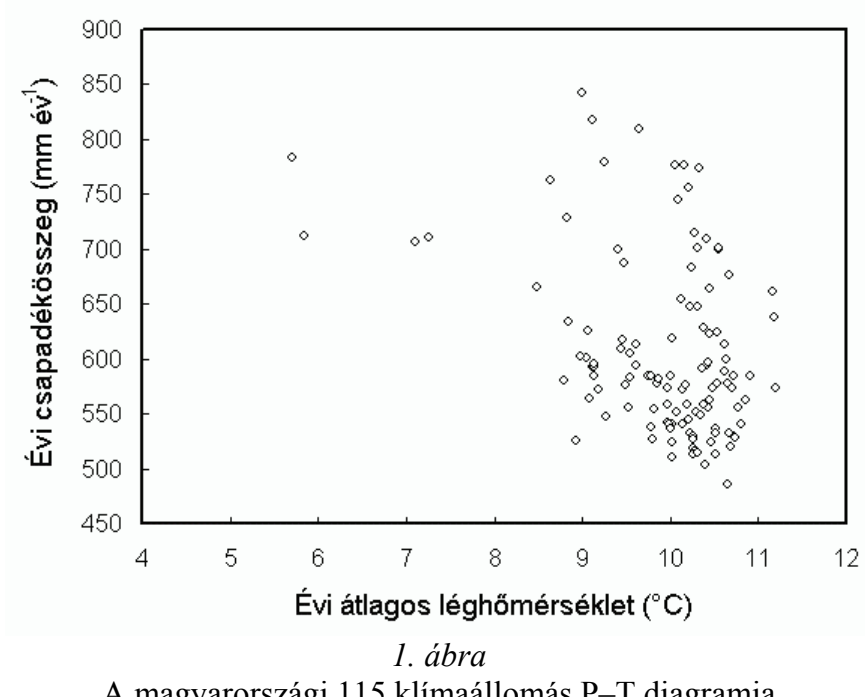

(az adatok az 1901-től 1950-ig terjedő időszakra vonatkoznak) 
kot, a homokos vályogot, a vályogot, az agyagos vályogot és az agyagot. A klímaállomások talajának fizikai féleségét VÁRALLYAY (1990) alapján határozzuk meg. A $\mathrm{VK}_{\mathrm{h}}$ és a $\mathrm{VK}_{\mathrm{sz}}$ értékeket NEMES (2003) munkája alapján állapítottuk meg (1. táblázat). NEMES (2003) munkájában a VAN GENUCHTEN-féle (1980) pF-görbékre vonatkozó paraméter értékek találhatók meg az USDA (United States Department of

\section{1. táblázat}

A hervadáspont $\left(\mathrm{VK}_{\mathrm{h}}\right)$ és szabadföldi vízkapacitás $\left(\mathrm{VK}_{\mathrm{sz}}\right)$ értékei a talaj öt különböző fizikai féleségére vonatkozóan

\begin{tabular}{|c|c|c|c|c|c|}
\hline \multirow{2}{*}{\begin{tabular}{c} 
Paraméter \\
\cline { 2 - 6 }
\end{tabular}} & $\begin{array}{c}(3) \\
\text { Homok }\end{array}$ & $\begin{array}{c}\text { (4) } \\
\text { Homokos } \\
\text { vályog }\end{array}$ & $\begin{array}{c}(5) \\
\text { Vályog }\end{array}$ & $\begin{array}{c}\text { Agyagos } \\
\text { vályog }\end{array}$ & $\begin{array}{c}(7) \\
\text { Agyag }\end{array}$ \\
\hline $\mathrm{VK}_{\mathrm{h}}\left(\mathrm{mm} \cdot \mathrm{m}^{-1}\right)$ & 15,2 & 104,7 & 135,5 & 175 & 271,9 \\
$\mathrm{VK}_{\mathrm{sz}}\left(\mathrm{mm} \cdot \mathrm{m}^{-1}\right)$ & 79,9 & 273,8 & 331,7 & 386,9 & 485,4 \\
\hline
\end{tabular}

Agriculture) klasszifikáció szerinti 11 talaj fizikai féleségre. A magyar és az USDA klasszifikáció közötti összefüggéseket FILEP és FERENCZ (1999) tanulmánya alapján vettük. A hervadáshoz tartozó vízkészletet a $\mathrm{pF}=4,2$, míg a szabadföldi vízkapacitáshoz tartozó talaj vízkészlet értéket a $\mathrm{pF}=2,5$ feltétel alapján számítottuk. Itt megemlítendő az is, hogy a $\mathrm{VK}_{\mathrm{sz}}$ értékének meghatározása más kritériumok alapján is lehetséges (ÁCS, 2005). A homok, a legnagyobb szemcseméretủ fizikai talajféleségként a legalacsonyabb $\mathrm{VK}_{\mathrm{h}}$ és $\mathrm{VK}_{\mathrm{sz}}$ talaj vízkészlet értékekkel jellemzett. $\mathrm{A}$ szemcseméret csökkenésével növekszik a $\mathrm{VK}_{\mathrm{h}}$ és a $\mathrm{VK}_{\mathrm{sz}}$ értéke is. A növekedés mértéke a homok és a homokos vályog között a legjelentösebb.

A Debreceni Agrometeorológiai Obszervatórium adatai. - A módosított Thornthwaite-féle modell jóságát a Debreceni Egyetem Hajdúháton $\left(47^{\circ} 37^{\prime} \mathrm{N}\right.$, $21^{\circ} 36^{\prime} \mathrm{E}, \mathrm{h}=112 \mathrm{~m}$ ) levő Agrometeorológiai Obszervatóriumának mért adatain (csapadék, hőmérséklet és a talaj vízkészlet adatok) teszteltük. Az állomás klímája mérsékelt kontinentális, az éves csapadékösszeg $550 \mathrm{~mm}$, az évi átlaghömérséklet 10,1 ${ }^{\circ} \mathrm{C}$. A talajvíz mélysége $10 \mathrm{~m}$ körül van, a talajtípus löszháton fekvő csernozjom, a fizikai féleség vályog, a növényzet nem rendszeresen kaszált gyep. A $\mathrm{VK}_{\mathrm{sz}}$ és a $\mathrm{VK}_{\mathrm{h}}$ értékekhez tartozó talaj vízkészlet 360 és $150 \mathrm{~mm} \cdot \mathrm{m}^{-1}$. Az adatok az 1972-től 1992-ig terjedő időszakra vonatkoznak. Az Obszervatóriumban hetente mértek talajnedvesség-tartalmat, a havi mérések száma egy és hat között változott. A téli időszakban a mérések gyakran szüneteltek fagy vagy hó miatt. A 21 év talaj vízkészlet adataiból 4 decemberi, 10 januári és 9 februári hónap hiányzik. A talajnedvességet gravimetriás módszerrel határoztuk meg. A mintavételek rövidre vágott gyeptakaróra vonatkoznak. A minták $0-5,5-10$, majd további $10 \mathrm{~cm}$-enkénti rétegekből származnak. A minták magassága és átmérője egyaránt $10 \mathrm{~cm}$. A rendszeres mintavétel $0-100 \mathrm{~cm}$-ig, időszakosan $150 \mathrm{~cm}$-ig terjedt. A kiemelt talajminták öszszekeverése után mintegy $200 \mathrm{~g}$ talaj szárítására került sor. A szárítás $105^{\circ} \mathrm{C}$-on 
történt súlyállandóságig. A száraz súlyt közvetlenül a szárítás után határoztuk meg. A talajnedvesség-mérés módszere a vizsgált időszakban azonos volt.

A megjelenitő rendszer. - A bemenő és a kimenő adatok területi eloszlását a SurGe Project Manager nevü program segítségével készítettük. A program az állomások koordinátái és a rajzolandó változók értékei alapján rácsot szerkeszt, majd interpolációval az adatokkal nem rendelkező rácspontokra, megjeleníti a mezőt. Az interpolációt az ún. „ABOS” módszer (Approximation/interpolation Based On Smoothing) alapján végzi (DRESSLER, 2003), ami a „kriging” és a „minimum görbület" módszer ötvözete. Az interpoláció pontossága hasonló a kriging módszeréhez.

\section{Eredmények}

\section{Verifikálási vizsgálatok}

A mért és a szimulált VK-értékek változásait és viszonyát az 1972-től 1992-ig tartó időszakban elemeztük. A mért és a szimulált talaj vízkészlet többéves átlagainak és szórásainak évi menete a 2 . ábrán látható.

A februári és a tavaszi hónapok kivételével $\left(\mathrm{VK}_{\text {mért }}-\sigma_{\text {mért }}<\mathrm{VK}<\mathrm{VK}_{\text {mért }}+\sigma_{\text {mért }}\right)$ a szimulált havi átlagok a mért havi átlagok átlagos szóródásán belül vannak. Ugyanakkor egyetlen olyan hónapunk sincs, amikor $\mathrm{VK}_{\text {szim }}-\sigma_{\text {szim }}>\mathrm{VK}_{\text {mért }}+\sigma_{\text {mért. }}$ A legnagyobb eltérések áprilisban és májusban vannak, ekkor a $\mathrm{VK}_{\text {szim }} \mathrm{kb} .75 \mathrm{~mm} \cdot \mathrm{m}^{-1}$-el nagyobb, mint a $\mathrm{VK}_{\text {mért }}$ ami 30\%-os eltérést jelent. A tavaszi eltérések nyilván a VK és az $\mathrm{S}$ modellezésével és mérésével kapcsolatosak. A tavaszi víztöbblet és vízkészlet változásának szimulálása és/vagy mérése egyébként összetett feladat,

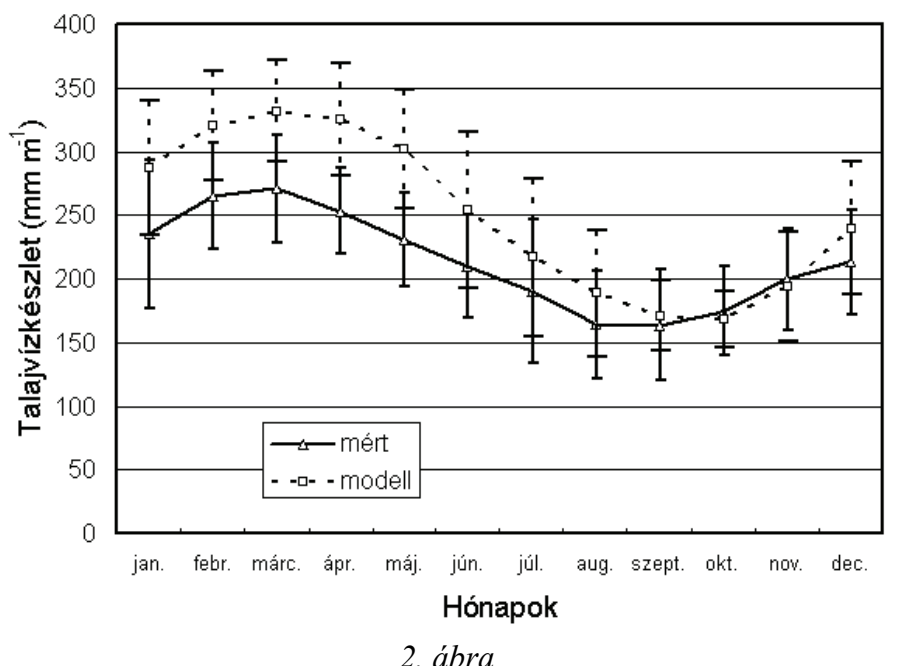

A mért és a szimulált talaj vízkészlet többéves átlagainak és szórásainak évi menete (A többéves átlagok és szórások az 1972-től 1992-ig tartó időszakra vonatkoznak) 
mivel a víz eloszlása ekkor egyaránt függ a talaj és a domborzat karakterisztikáitól. A tavaszi vízkészlet és lefolyás közötti eloszlás problémájának mélyebb megértése és kezelése a jövőbeni feladataink egyike. Említsük meg azt is, hogy a párolgás számítása szempontjából - ami végül is e tanulmány célja - a tavaszi vízbőség ala-

\section{2. táblázat}

A párolgás (ET) és talaj vízkészlet (VK) kapcsolata a csapadékkal és hőmérséklettel a 115 klímaállomás fizikai talajfélesége és a kiválasztott időtartam szerint

\begin{tabular}{|c|c|c|c|c|c|c|c|c|c|c|}
\hline \multirow{3}{*}{$\begin{array}{c}(1) \\
\text { Időszak }\end{array}$} & \multicolumn{10}{|c|}{ (2) A talaj fizikai félesége } \\
\hline & \multicolumn{2}{|c|}{$\begin{array}{l}(3) \\
\text { Homok }\end{array}$} & \multicolumn{2}{|c|}{$\begin{array}{l}\text { (4) } \\
\text { Homokos } \\
\text { vályog }\end{array}$} & \multicolumn{2}{|c|}{$\begin{array}{c}(5) \\
\text { Vályog }\end{array}$} & \multicolumn{2}{|c|}{$\begin{array}{l}\text { (6) } \\
\text { Agyagos } \\
\text { vályog }\end{array}$} & \multicolumn{2}{|c|}{$\begin{array}{l}(7) \\
\text { Agyag }\end{array}$} \\
\hline & & $\mathrm{R}^{2}$ & & $\mathrm{R}^{2}$ & & $\mathrm{R}^{2}$ & & $\mathrm{R}^{2}$ & & $\mathrm{R}^{2}$ \\
\hline \multicolumn{11}{|c|}{$\begin{array}{c}\text { A. A párolgás (ET) statisztikai kapcsolata a léghömérséklettel (T), a csapadékkal (P) } \\
\text { és az aktuális vizkészlettel (VK) }\end{array}$} \\
\hline január & - & - & - & - & - & - & - & - & - & - \\
\hline február & - & - & $\mathrm{T}$ & 0,64 & - & - & - & - & - & - \\
\hline március & $\mathrm{T}$ & 0,93 & $\mathrm{~T}$ & 0,81 & $\mathrm{~T}$ & 0,84 & $\mathrm{~T}$ & 0,95 & $\mathrm{~T}$ & 0,98 \\
\hline április & $\mathrm{T}$ & 0,93 & $\mathrm{~T}$ & 0,90 & $\mathrm{~T}$ & 0,86 & $\mathrm{~T}$ & 0,97 & $\mathrm{~T}$ & 0,88 \\
\hline május & $\mathrm{T}$ & 0,68 & $\mathrm{P}$ & 0,94 & $\mathrm{~T}$ & 0,85 & $\mathrm{~T}$ & 0,99 & $\mathrm{~T}$ & 0,58 \\
\hline június & VK & 0,92 & $\mathrm{~T}$ & 0,74 & $\mathrm{~T}$ & 0,89 & $\mathrm{~T}$ & 0,99 & $\mathrm{~T}$ & 0,58 \\
\hline július & $\mathrm{P}$ & 1 & $\mathrm{P}$ & 0,97 & VK & 0,72 & VK & 0,55 & VK & 0,97 \\
\hline augusztus & $\mathrm{P}$ & 1 & $\mathrm{P}$ & 0,98 & $\mathrm{P}$ & 0,94 & VK & 0,85 & $\mathrm{P}$ & 1 \\
\hline szeptember & $\mathrm{P}$ & 1 & $\mathrm{P}$ & 0,99 & $\mathrm{P}$ & 0,99 & $\mathrm{P}$ & 0,92 & $\mathrm{P}$ & 1 \\
\hline október & $\mathrm{T}$ & 0,93 & $\mathrm{~T}$ & 0,79 & $\mathrm{~T}$ & 0,82 & $\mathrm{~T}$ & 0,96 & $\mathrm{~T}$ & 0,96 \\
\hline november & $\mathrm{T}$ & 0,94 & $\mathrm{~T}$ & 0,77 & $\mathrm{~T}$ & 0,85 & $\mathrm{~T}$ & 0,94 & $\mathrm{~T}$ & 0,99 \\
\hline december & $\mathrm{T}$ & 0,79 & $\mathrm{~T}$ & 0,94 & $\mathrm{~T}$ & 0,88 & - & - & $\mathrm{T}$ & 0,99 \\
\hline a) év & $\mathrm{P}$ & 0,93 & $\mathrm{P}$ & 0,90 & $\mathrm{P}$ & 0,88 & - & - & $\mathrm{P}$ & 0.98 \\
\hline \multicolumn{11}{|c|}{$\begin{array}{c}\text { B. A talaj vízkészlet (VK) statisztikai kapcsolata a léghömérséklettel (T), a csapadékkal (P) } \\
\text { és a párolgással (ET) }\end{array}$} \\
\hline január & - & - & $\mathrm{P}$ & 0,68 & $\mathrm{P}$ & 0,66 & $\mathrm{P}$ & 0,79 & $\mathrm{~T}$ & 0,61 \\
\hline február & - & - & - & - & - & - & $\mathrm{P}$ & 0,53 & - & - \\
\hline március & - & - & - & - & - & - & - & - & - & - \\
\hline április & $\mathrm{P}$ & 0,75 & $\mathrm{P}$ & 0,64 & $\mathrm{P}$ & 0,52 & $\mathrm{P}$ & 0,51 & - & - \\
\hline május & $\mathrm{P}$ & 0,86 & $\mathrm{P}$ & 0,88 & $\mathrm{P}$ & 0,77 & $\mathrm{P}$ & 0,92 & - & - \\
\hline június & ET & 0,92 & $\mathrm{P}$ & 0,84 & $\mathrm{P}$ & 0,46 & $\mathrm{~T}$ & 0,81 & $\mathrm{P}$ & 0,76 \\
\hline július & - & - & ET & 0,85 & $\mathrm{P}$ & 0,74 & $\mathrm{~T}$ & 0,90 & ET & 0,97 \\
\hline augusztus & - & - & ET & 0,87 & ET & 0,76 & $\mathrm{~T}$ & 0,87 & - & - \\
\hline szeptember & - & - & $\mathrm{P}$ & 0,72 & $\mathrm{P}$ & 0,60 & $\mathrm{~T}$ & 0,81 & - & - \\
\hline október & $\mathrm{P}$ & 0,70 & $\mathrm{P}$ & 0,82 & - & - & $\mathrm{T}$ & 0,76 & - & - \\
\hline november & $\mathrm{P}$ & 0,75 & $\mathrm{P}$ & 0,91 & - & - & $\mathrm{P}$ & 0,82 & - & - \\
\hline december & - & - & $\mathrm{P}$ & 0,96 & $\mathrm{P}$ & 0,68 & $\mathrm{P}$ & 0,79 & - & - \\
\hline a) év & $\mathrm{P}$ & 0,86 & $\mathrm{P}$ & 0,96 & $\mathrm{P}$ & 0,89 & $\mathrm{P}$ & 0,91 & ET & 0,88 \\
\hline
\end{tabular}

Megjegyzés: -: Nincs egy olyan kapcsolat sem, amely elérte volna a szignifikancia szintet. A 115 klímaállomás talajának fizikai félesége a következőképpen oszlik meg: homok: 16; homokos vályog: 9; vályog: 63 ; agyagos vályog: 21 , agyag: $7 . \mathrm{R}^{2}=$ determinációs együttható 
kulásának becslése nem fontos, mivel a párolgás potenciális viszonyok között történik.

A januári és a februári hónapokban jelentkező eltérések a hótakaró és/vagy a talajjég olvadását és fagyását szimuláló folyamatok bevezetésével küszöbölhetők ki. Ehhez nélkülözhetetlen az energiaháztartási egyenlet alkalmazása, amivel a modell egyenlöre nem rendelkezik.

\section{Statisztikai elemzések}

A párolgás (ET) és a talaj vízkészlet (VK) csapadékkal (P) és hőmérséklettel (T) való statisztikai kapcsolatát lineáris regresszióval jellemeztük a talajok fizikai félesége és a kiválasztott időtartam [hónap, tenyészidőszak (március-novemberi időszak) és év] szerint. A legerősebb kapcsolatok, melyek elérték a kívánt $\mathrm{P}=0,01$ szignifikancia szintet, valamint a determinációs együtthatók $\left(\mathrm{R}^{2}\right)$ a 2 . táblázatban láthatók.

Az ET télen mindössze néhány mm az alacsony hömérsékletek miatt. Decemberben - a legmelegebb téli hónapban - még van szignifikáns kapcsolat az ET és T között, de januárban már nincs. Februárban szignifikáns kapcsolatot csak a homokos vályog esetében találtunk. Márciusban a VK megközelíti a VK $\mathrm{sz}_{\mathrm{sz}}$ étékét (lásd a 3A. ábrát), ezért a további csapadék már nem befolyásolja a párolgást. A hőmérséklet emelkedésével a párolgás nő, így márciustól májusig 15-ről 90 mm-re emelkedik. E növekvő párolgás nagyobb, mint a lehulló csapadék, így a talaj vízkészlet csökken. Az ET és a $\mathrm{T}$ kapcsolatát jellemző $\mathrm{R}^{2}$ értéke a tavaszi időszakban átlagosan 0,87 körüli, de 0,95 is előfordulhat, ami erős kapcsolatot jelent figyelembe véve, hogy az ET egyaránt függ a T-töl és a VK-tól. Júniusig a homokos területek vízkészlete jelentősen lecsökken (lásd a $3 \mathrm{~A}$. ábrát). Ekkor a talaj kis vízkészlete határozza meg a párolgást. Júliusban és augusztusban a talaj már majdnem teljesen száraz, ezért ekkor már a csapadék a meghatározó elem. E hónapokban az összes lehullott csapadék elpárolog a magas hőmérsékletek miatt. Szeptemberben a talaj vízkészlete megközelíti a $\mathrm{VK}_{\mathrm{h}}$ értékét mind az 5 fizikai félesége esetében. A párolgás ekkor kisebb, mint nyáron, s ezért a csapadékkal való korreláció a meghatározó. Októberben és novemberben a P és a VK egyaránt nagy, így az ET-t a csökkenő T határozza meg. Az évi ET esetében a csapadék a meghatározó elem.

Most vizsgáljuk meg a VK kapcsolatrendszerét! Márciusban a nagy VK értékek miatt egyetlen egy szignifikáns kapcsolat sincs. Áprilisban az $\mathrm{R}^{2}$ értékek 0,6 körüliek, elsősorban a nagy VK értékek miatt. Nyáron előtérbe kerül az ET és a T hatása az állandóan csökkenő VK miatt. Összel a VK-t újból a P határozza meg. Szeptemberben, amikor nagy a talajszárazság az $\mathrm{R}^{2}$ értékek valamelyest kisebbek, mint októberben és novemberben. Vályog esetén októberben és novemberben az $\mathrm{R}^{2}$ értéke olyan kicsi, hogy a VK és a P közötti kapcsolat nem is szignifikáns. Az évi VK esetében szintén a csapadék a meghatározó elem. 


\section{A talaj vizkészlet és a tényleges párolgás évi menete}

A számított talaj vízkészlet (VK) és tényleges párolgás (ET) átlagos évi menete a talajok fizikai félesége szerint a 3. ábrán látható. A 115 klímaállomás talaj fizikai féleség kategóriák szerinti megoszlása a következő: homok: 16, homokos vályog: 9 , vályog: 63, agyagos vályog: 21 és agyag: 7 .

A VK évi változása hasonló a verifikációs vizsgálatban kapott évi változáshoz (lásd a 2. ábrát). A homok elkülönül a többi fizikai féleségtől, feltehetően a kis víztartó képessége miatt. Az agyagra vonatkozó évi menet a legszembetünőbb. A tavaszi maximum nagyobb, mint a januári érték, és az őszi aszályhoz tartozó minimális érték sem olyan kicsi, mint a többi fizikai féleség esetén.

\section{$\mathbf{A}$}
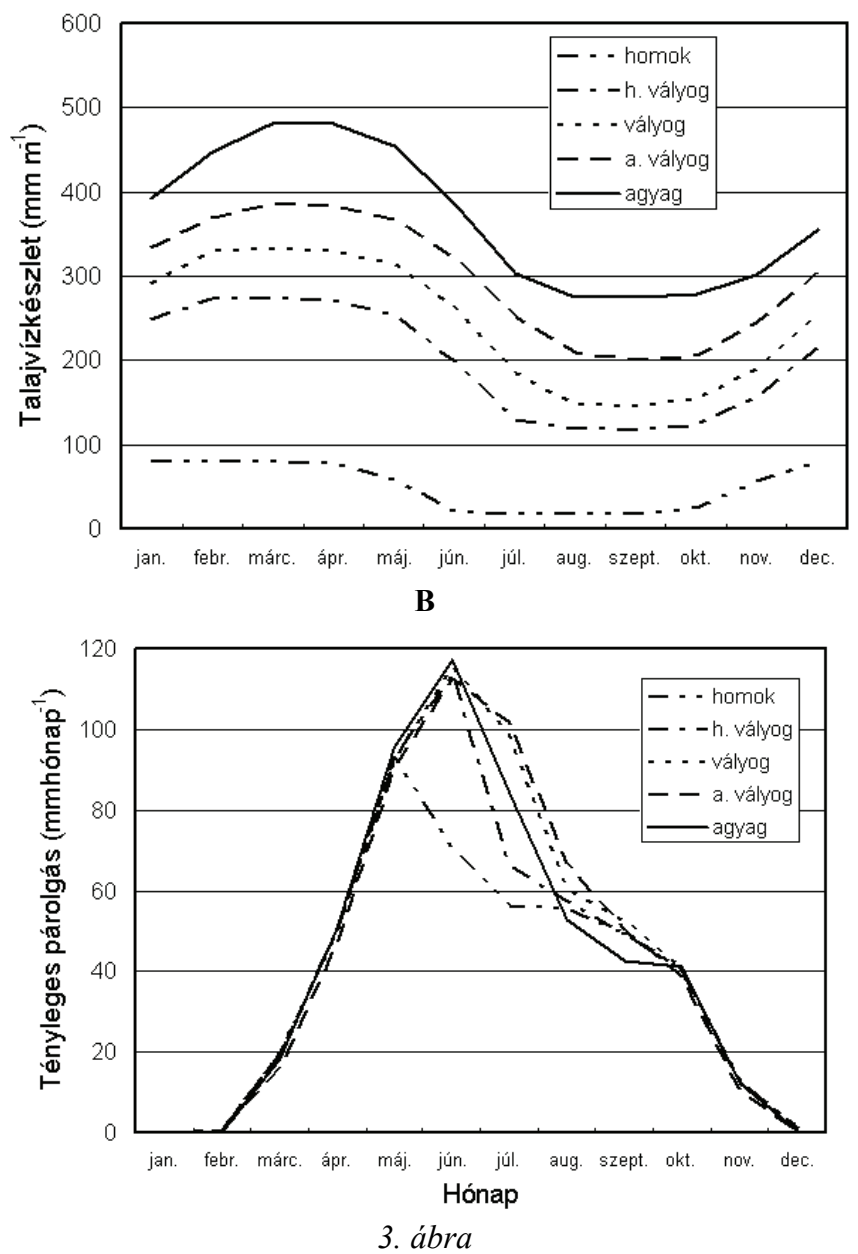

A talaj vízkészlet (A), ill. a tényleges párolgás (B) átlagos évi menete homok, homokos vályog, vályog, agyagos vályog és agyag fizikai féleség esetén 
A párolgás (ET) évi menete hasonló a T évi menetéhez. Júniusban maximuma, míg januárban minimuma van. A homok esetén a maximum májusban van. Júniustól augusztusig az ET jelentős mértékben csökken, míg augusztustól októberig e csökkenés mértéke kisebb.

\section{A területi eloszlások vizsgálata}

Évi értékek területi eloszlása. - Az átlagos évi VK területi eloszlását (4A. ábra) nagymértékben a talaj fizikai féleségének a területi eloszlása határozza meg. A
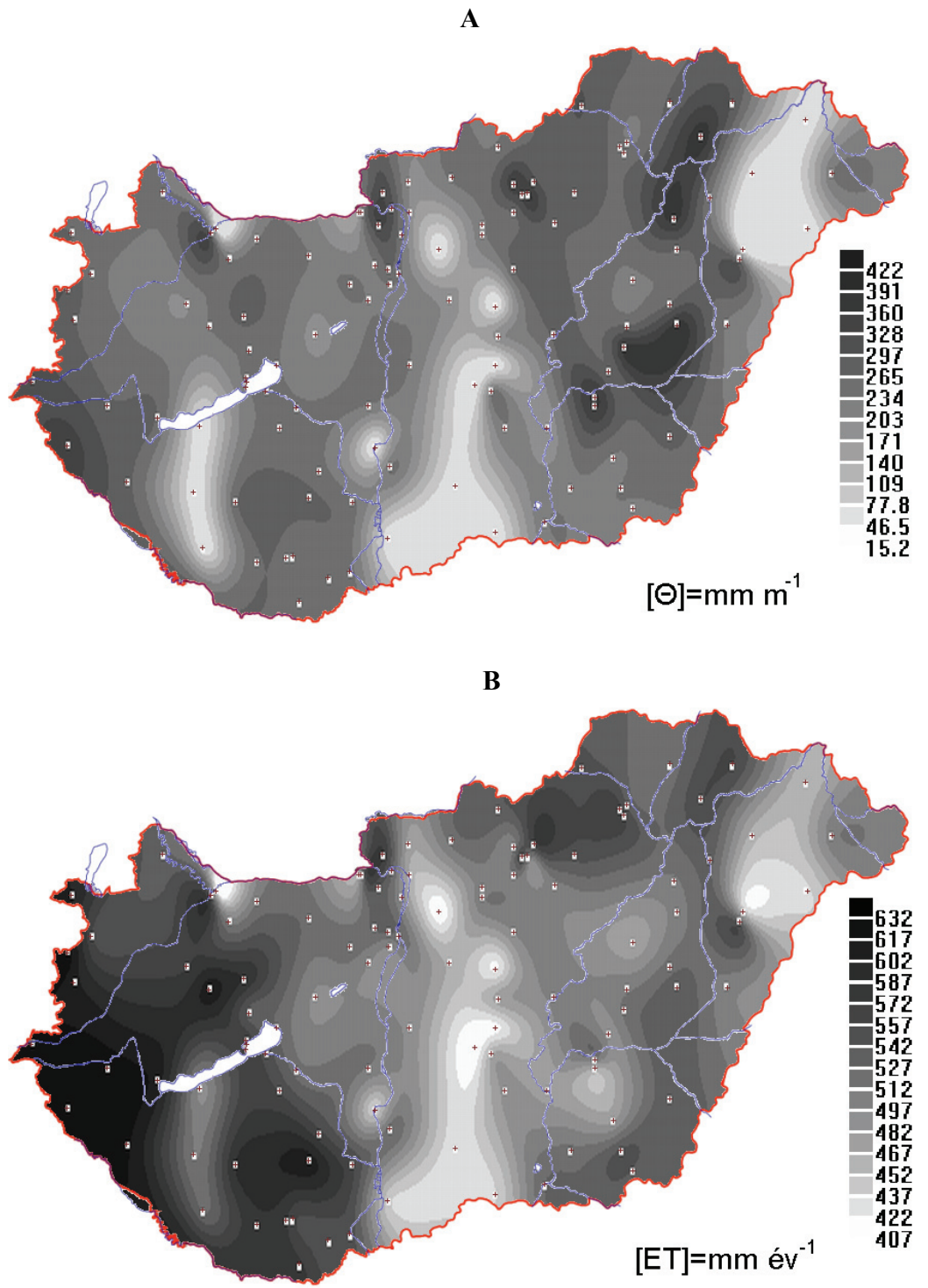


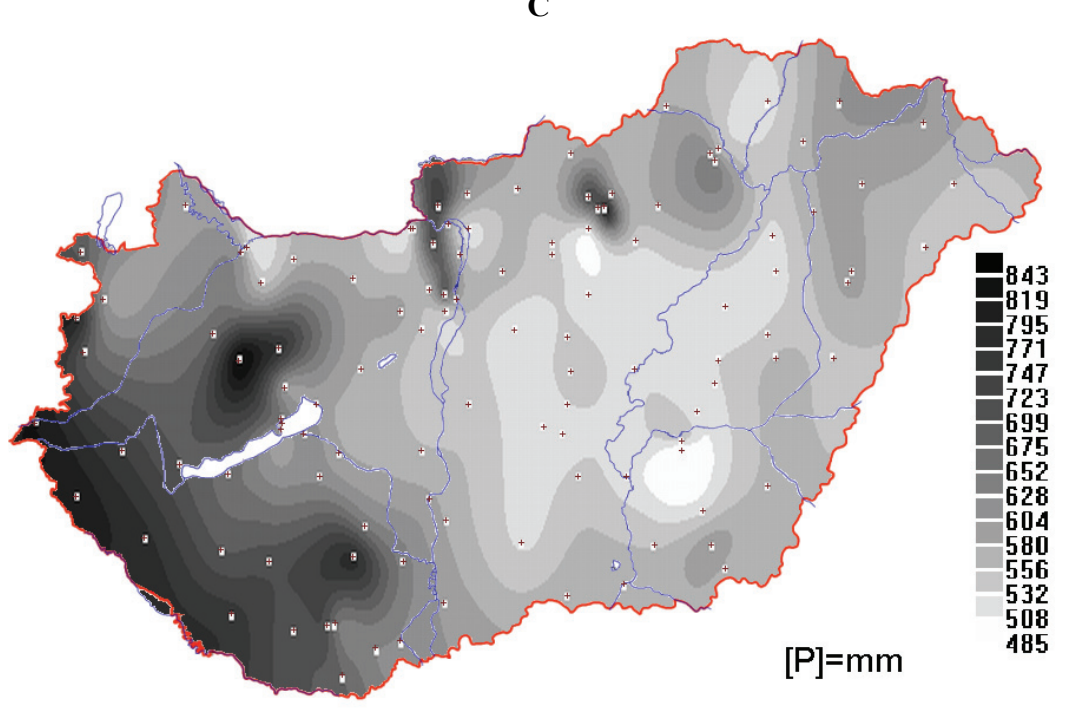

4. ábra

Az évi átlagos talaj vízkészlet (VK) (A), a párolgás (ET) évi összegének (B), ill. a csapadék $(\mathrm{P})(\mathrm{C})$ évi összegének területi eloszlása Magyarországon

legkisebb VK értékek a homokos, míg a legnagyobbak az agyagos területeken fordulnak elő. A nagy homokos területeken - a Nyírségben, a Gödöllöi-dombságon, a Felső- és az Alsó-Kiskunságban, Paks környékén, a Szigetköz déli részén, a Tapolcai-medencében és Belső-Somogyban - az évi átlagos VK érték $30-50 \mathrm{~mm} \cdot \mathrm{m}^{-1}$. Az agyagos és az agyagos vályog területeken - pl. Tokaj-hegyalján, a Taktaközben, a Hortobágy északi részén, a Mátrában, a Börzsönyben, a Visegrádi-hegységben, a Dévaványai-síkon, a Hajdúságban, a Nagykunság déli részén és a Békési-sík nyugati részén - a VK átlagosan $320-390 \mathrm{~mm} \cdot \mathrm{m}^{-1}$. A vályogos területü Zselicre és Zalaidombságra a $280-300 \mathrm{~mm} \cdot \mathrm{m}^{-1} \mathrm{VK}$ a jellemzö, amely valamelyest nagyobb, mint a hasonló vályogos területek VK értékei. Ezt elsősorban a csapadékbeli különbségek eredményezik (lásd a 4C. ábrát).

A tényleges párolgás évi összegének területi eloszlása (4B. ábra) jelentős mértékben függ mind a talaj vízkészletétől, mind a csapadéktól (2. táblázat, $4 \mathrm{C}$. ábra). Az ET minimumok (407-470 mm·év $\left.{ }^{-1}\right)$ és maximumok $\left(580-630 \mathrm{~mm} \cdot \mathrm{ev}^{-1}\right)$ területi eloszlása megközelítően egybeesik a VK szélsőértékek eloszlásával. A Körös-zug, a Jászság és a Csepeli-sík párolgása a kis csapadék miatt azonban kisebb, mint az ugyanilyen fizikai féleséggel rendelkező területek párolgása. A csapadékosabb délnyugati országrészben az ET évi összege $600 \mathrm{~mm} \cdot \mathrm{év}^{-1}$ körül van.

Havi értékek területi eloszlása. - Tavasszal az ET-t a T határozza meg (2. táblázat). Márciusban az ET 5 és $25 \mathrm{~mm}$ hónap ${ }^{-1}$ értékek közötti (5A. ábra). A párolgás a Mátrában, a Visegrádi-hegységben, a Pilisben és a Miskolci-kapunál a legkisebb, míg a Szeged és Kiskunfélegyháza közötti vonalon, a Pesti-síkságon, a Marcali- 
medencében, a Mezőföldön és Délnyugat-Magyarországon - a Tolnai-hegyhát kivételével - pedig a legnagyobb. Ha összehasonlítjuk az ET területi eloszlását a márciusi hónap átlagos hőmérsékletének területi eloszlásával (5B. ábra), láthatjuk, hogy az ET és a T szélsőértékeinek területi eloszlása nagyon hasonló.
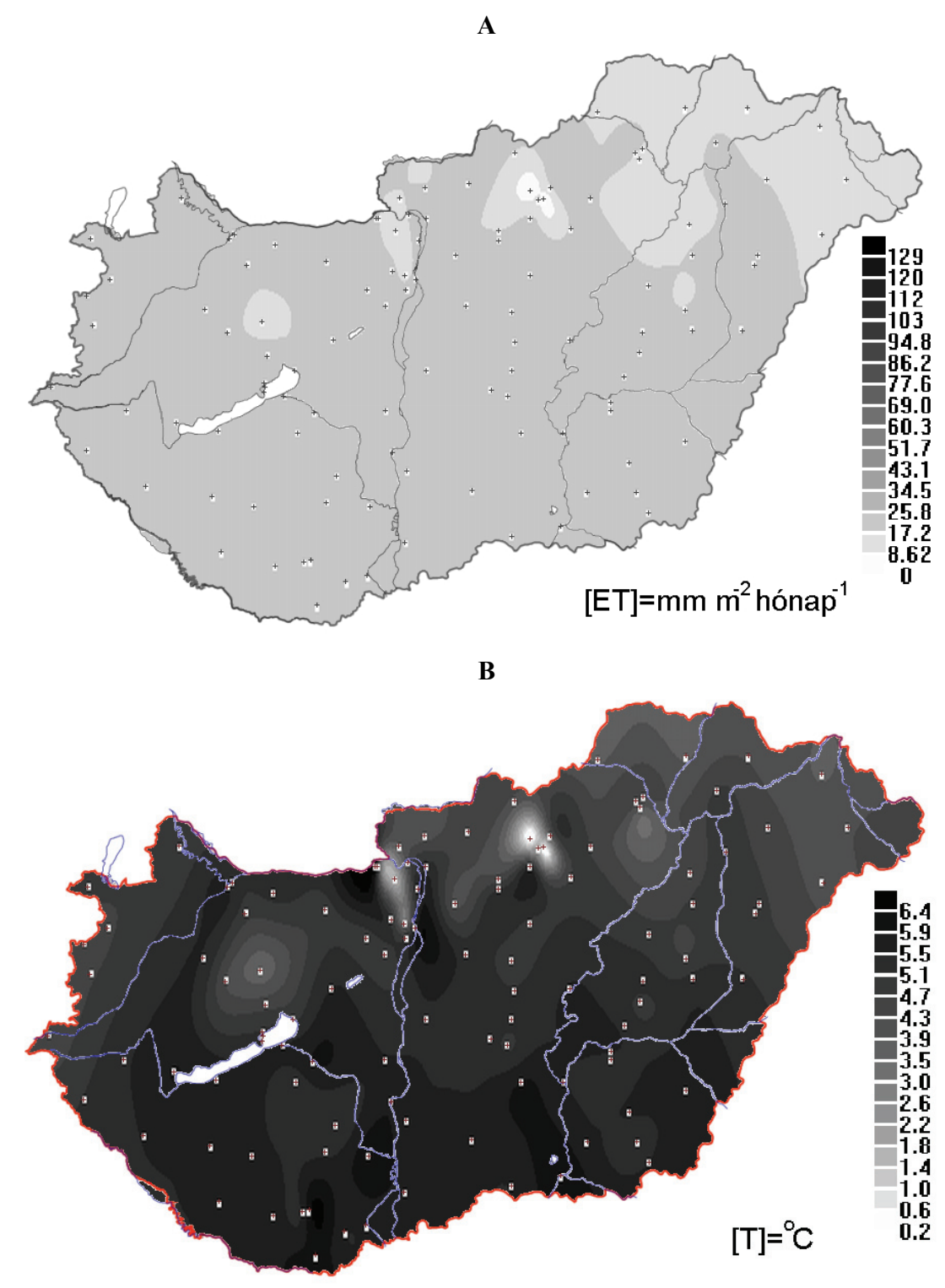

5. ábra

A tényleges párolgás (ET) (A) és a léghőmérséklet (T) (B) területi eloszlása márciusban Magyarországon 
Az ET és a VK területi eloszlása júniusban (6A. és a 6B. ábra) szinte azonos az évi ET (4B. ábra) és VK (4A. ábra) területi eloszlásával. A legkisebb ET értékek (40-75 mm·hónap $\left.{ }^{-1}\right)$ a Nyírségben, a Pesti-síkságon, a Felső- és Alsó-Kiskunságban, Illancson, a Belsö-Somogyban és a Tapolcai-medencében fordulnak elö. Az ET legnagyobb értékei a Mosoni-sík keleti részén, Sokorón, a Mezőföld északi

A

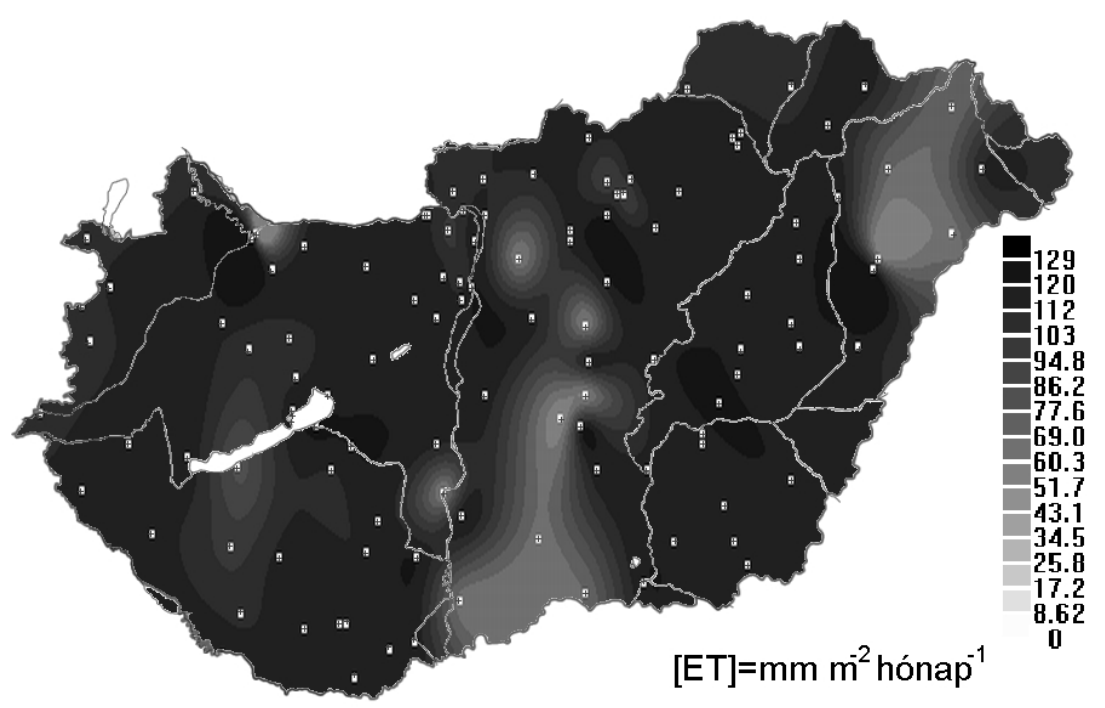

B

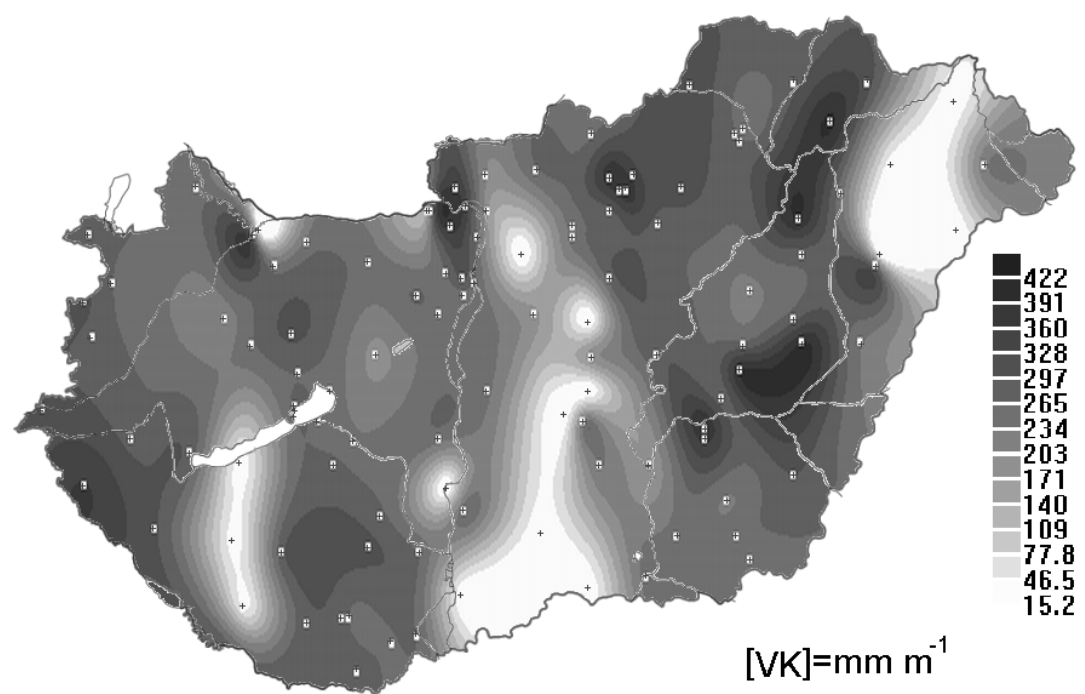

6. ábra

A tényleges párolgás $(\mathrm{ET})(\mathrm{A})$ és a talaj vízkészlet $(\mathrm{VK})(\mathrm{B})$ területi eloszlása júniusban Magyarországon 
részén, a Gyöngyösi-síkon, a Hajdúság déli részén, a Dévaványai-síkon és a Békésisíkon vannak. Itt az ET 110-130 mm·hónap ${ }^{-1}$ értékek között változik. Az ET és VK szélsőértékeinek területi eloszlása nagyrészt egybeesik. Ez azonban nem mindenhol érvényesül, előfordulnak jelentősebb eltérések is. Ilyen pl. a Mátra esete, ahol az ET értéke kicsi, a VK-é pedig nagy, vagy a Balaton-környéki területek, ahol fordított a helyzet. A Mátra esetében az ET kicsi, mert a T alacsony, míg a Balaton-környéki területek esetében az ET a nagy P miatt nagyobb.
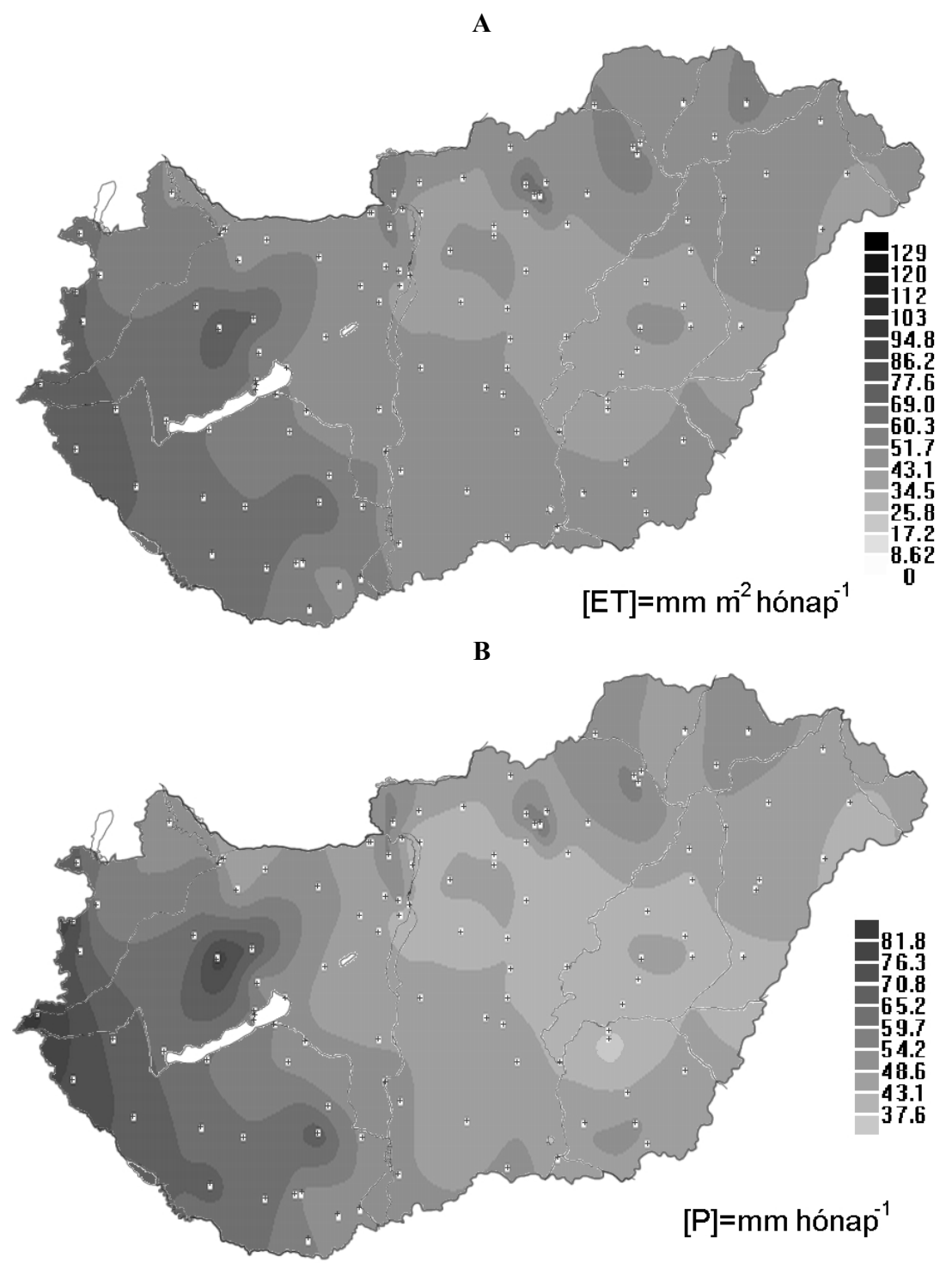

7. ábra

A tényleges párolgás $(\mathrm{ET})(\mathrm{A})$ és a csapadék $(\mathrm{P})(\mathrm{B})$ területi eloszlása szeptemberben 
A 3A. ábrán látható, hogy augusztus és szeptember a legszárazabb (a legkisebb VK értékkel rendelkezö) hónapok. Kis VK értékek esetén a legkisebb mennyiségü $\mathrm{P}$ is nagy változást okoz a párolgásban. Ezt kiválóan illusztrálja a 7A. és 7B. ábra, ugyanis az ET területi eloszlása szinte teljesen megegyezik a P területi eloszlásával. Ott, ahol a P a legkisebb, ott az ET 40-45 mm·hónap ${ }^{-1}$ közötti. Nyugat felé haladva a Jászság-Békés vonalon a P növekedésével az ET is növekszik. Az ET a Mátrában, az Észak-Bakonyban, a Mecsekben és az Alpok-alján a legnagyobb, ahol 60-85 $\mathrm{mm} \cdot$ hónap $^{-1}$ érték körül van.

\section{Az eredmények értékelése}

A párolgás mezoklimatológiai jellemzőit (évszakos változás, területi eloszlás) egy módosított Thornthwaite-féle modell (THORNTHWAITE, 1948) alapján elemeztük Magyarországra vonatkozóan. A módosított Thornthwaite-modellben a potenciális párolgás mellett a tényleges párolgást is becsüljük, számításba véve a tényleges párolgásnak a talaj fizikai féleségétöl való függését. A modell nem tesz különbséget a csupasz talaj és a növényzet között; a növényzet típusát egységesen gyepként kezeljük. A gyep referenciaként elfogadott a növényi párolgás tanulmányozásában (SHUTTLEWORTH, 1991). A modell 1 m-es mélységü talajszelvénnyel és gyökérzónával számol.

Eredményeink szerint az évi átlagos talaj vízkészlet (VK) $\mathrm{kb} .40-400 \mathrm{~mm} \cdot \mathrm{m}^{-1}$. A legkisebb értékek homokos területeken vannak az évi csapadékösszeg területi eloszlásától függetlenül. A legnagyobb értékeket agyagos területeken találjuk, de ezek területi eloszlását az évi csapadékösszeg területi eloszlása is meghatározza. Az évi VK területi eloszlása egyre jobban függ az évi csapadékösszeg területi eloszlásától, ahogy a talajok fizikai félesége a durvábbtól a finomabb felé halad.

A tényleges párolgás (ET) évi összege $\mathrm{kb}$. $400-650 \mathrm{~mm}$, amely 3-4-szerese a hasznos vízkészlet átlagos értékének (130-180 mm). Az évi ET és az évi VK területi eloszlása nagyon hasonló. Mondhatjuk azt is, hogy az évi ET területi eloszlását az évi VK területi eloszlása határozza meg, mely viszont a talaj fizikai féleségétől és az évi csapadékösszeg területi eloszlásától függ. Tavasszal a párolgás potenciális s a talaj fizikai féleségétôl sem függ (lásd a 3B. ábrát). Ekkor az ET területi eloszlását a hőmérséklet $(\mathrm{T})$ területi eloszlása határozza meg. Összel a tényleges párolgást a kis VK (szeptember), valamint az alacsony T (október és november) értékek határozzák meg. Októberben és novemberben az ET szintén független a talaj fizikai féleségétöl (3B. ábra). Ezzel szemben nyáron az ET nagymértékben függ a talaj fizikai féleségétől és a csapadék területi eloszlásától.

Az eredményeket terep vagy müholdas megfigyelések segítségével nem tudtuk igazolni, de megfelelnek tapasztalati elvárásainknak (pl. a talaj fizikai féleségétől és a csapadék területi eloszlásától való függés). Kihangsúlyozandó azonban az is, hogy ez az első olyan vizsgálat, amelynek során részletesen elemeztük a tényleges párolgás és a talajjellemzők közötti kapcsolatot mezoskálán.

Magyarországon a párolgást a felszíni tényezők közül alapvetően a domborzat és a talajtulajdonságok, valamint a növényborítás határozzák meg. A domborzati 
hatást a hőmérsékleti és csapadékadatokon keresztül vettük figyelembe. A modell a talaj hatását explicit módon kezeli.

A mezoskálájú párolgás becsléséhez a számítások tovább pontosíthatók a domborzati tényezők explicit módon történő számításba vételével. A domborzatot is figyelembe vevő modell országunk mikroskálájú hidroklímájának (km-es nagyságrendủ térbeli felbontás) becslésére is alkalmas lenne. E modell kidolgozása a jövő feladataink egyike.

\section{Összefoglalás}

Jelen közlemény a párolgás és a talaj vízkészlet magyarországi mezoklimatológiai jellemzőinek elemzésével foglalkozik. Az elemzést egy módosított Thornthwaite-féle (THORNTHWAITE, 1948) modell eredményei alapján végezzük. A tényleges párolgás becslése során a Thornthwaite-féle PET (potenciális evapotranszspiráció), valamint a Mintz és Walker-féle $\beta$ függvényt (MINTZ \& WALKER, 1993) alkalmazzuk. A talaj vízkészlet becslése során egy másodrendủ implicit numerikus sémát használtunk. A modell jóságát a Debreceni Agrometeorológiai Obszervatórium 21 éves adatsorán teszteltük.

Részletesen elemeztük a tényleges párolgás (ET), a talaj vízkészlet (VK) és a környezeti tényezők közötti statisztikai kapcsolatokat.

A legkisebb VK értékek homokos területeken vannak függetlenül attól, hogy milyen az évi csapadékösszeg területi eloszlása. A legnagyobb VK értékek agyagos területeken fordulnak elő, de ezek területi eloszlását az évi csapadékösszeg területi eloszlása is meghatározza. Az átlagos évi VK területi eloszlásának az évi csapadékösszeg területi eloszlásától való függése növekszik, ahogy a talajok fizikai félesége a durvábbtól a finomabb irányába halad.

Az évi ET és évi VK területi eloszlása nagyon hasonló. Tavasszal, ősszel és télen az ET független a talaj fizikai féleségétől, míg nyáron az ET erősen függ a talaj fizikai féleségétől és a csapadék területi eloszlásától.

Kulcsszavak: tényleges párolgás, talaj vízkészlet, Thornthwaite-féle modell, tenyészidőszak, mezoskála

A munka a T 043695. számú OTKA pályázat támogatásával készült.

\section{Irodalom}

Ács, F., 2005. On transpiration and soil moisture content sensitivity to soil hydrophysical data. Boundary-Layer Meteorology. 115. 473-497.

ÁCs, F., SZÁsz, G. \& DRUCZA, M., 2005,. Estimating soil moisture content of a grasscovered surface using an energy balance approach and agroclimatological observations. Időjárás. 109. 71-88. 
BERÉNYI D., 1943. Magyarország Thornthwaite rendszerü éghajlati térképe és az éghajlati térképek növényföldrajzi vonatkozásai. Időjárás. 47. (5-6) 81-91. (7-8) 117125.

DRESSLER, M., 2003. http://www.geocities.com/miroslavdressler/surgemain.htm.

FILEP GY. \& FERENCZ G., 1999. Javaslat a magyarországi talajok szemcseösszetétel szerinti osztályozásának pontosítására. Agrokémia és Talajtan. 48. 305-320.

KAKAS J., 1960. A lehetséges évi evapotranspiráció. Az évi vízfölösleg. Az évi vízhiány. In: Magyarország Éghajlati Atlasza. 46. Akadémiai Kiadó. Budapest.

Magyarország Klíma Atlasza, 2000. Országos Meteorológiai Szolgálat. Budapest.

MANABE, S., 1969. Climate and ocean circulation. 1. The atmospheric circulation and the hydrology of the earth's surface. Mon. Weather Rev. 97. 739-774.

MCKenney, M. S. \& RosenberG, N. J., 1993. Sensitivity of some potential evapotranspiration estimation methods to climate change. Agric. For. Meteorol. 64. 81110.

MintZ, Y. \& WAlKeR, G. K., 1993. Global fields of soil moisture and land surface evapotranspiration derived from observed precipitation and surface air temperature. J. Appl. Meteorol. 32. 1305-1335.

MocKO, D. M. \& SUD, Y. C., 1998. Comparison of a land surface model (SSiB) to three parameterizations of evapotranspiration - A study based on ISLSCP initiative I data. Earth Interactions. 2. 1-35.

Monteith, J. L., 1965. Evaporation and environment. In: Proc. $19^{\text {th }}$ Symp. Soc. Exp. Biol. 205-236. Cambridge University Press. Cambridge.

Monteith, J. L., 1995. Accomodation between transpiring vegetation and the convective boundary layer. J. Hydrol. 166. 251-263.

NEMES, A., 2003. Multi-scale hydraulic pedotransfer functions for Hungarian soils. PhD Dissertation. Wageningen University. Wageningen.

Posza I. \& STOLláR A., 1983. A tényleges párolgás számításához használt növénykonstansok értékei többévi mérés alapján. Időjárás. 87. 170-177.

ShutTleworTH, J. W., 1991. Evaporation Models in Hydrology. In: Land Surface Evaporation: Measurement and Parameterization. (Eds.: ShMugge, T. J. \& ANDRÉ, J.-C.) 93-120. Springer Verlag. New York-Berlin-Heidelberg.

Stone, P.H., S. ChOW and W.I. QuIRK, 1977. July climate and a comparison of the Jaunary and July climates simulated by the GISS general circulation model. Mon. Wea. Rev.. 105. 170-194.

SzÁsz G., 1963. A vízháztartás klimatikus tényezőinek vizsgálata Magyarországon. Debreceni Agrártudományi Főiskola Tudományos Közleményei. 1963. 49-71.

SzÁsz G., 1988. Agrometeorológia - általános és speciális. Mezőgazdasági Kiadó. Budapest.

SZEPESINÉ L. A., 1966: A Kárpát-medence hidroklímájának jellemzői. Beszámolók az 1965-ben végzett tudományos kutatásokról. Az Országos Meteorológiai Intézet hivatalos kiadványai. XXIX. 86-114.

SZESZTAY, K., 1958. Estimation of water balance of catchment areas in Hungary. Időjárás. 62. 313-328.

THORNTHWAITE, C. W., 1948. An approach toward a rational classification of climate. Geographical Rev. 38. 5-94.

VAN GENUCHTEN, M. T., 1980. A closed-form equation for predicting the hydraulic conductivity of unsaturated soils. Soil Sci. Soc. Am. J. 44. 892-898. 
VÁRALLYAY, Gy., 1990. Influences of climate changes on soil moisture regime, texture and erosion. In: Soils on a Warmer Earth. (Eds.: ScharpenseEl, H. W., SCHOMAKER, M. \& AYOUB, A.) 39-49. Elsevier. Amsterdam.

Érkezett: 2007. október 15. 


\title{
Estimation of actual evapotranspiration and soil water content in the growing season
}

\author{
${ }^{1}$ F. ÁCS, ${ }^{1}$ H. BREUER and ${ }^{2}$ G. SZÁSZ \\ ${ }^{1}$ Department of Meteorology, Eötvös Loránd University, Budapest and \\ ${ }^{2}$ Agrometeorology Observatory of Debrecen University, Debrecen
}

\section{Summary}

The paper deals with the mesoclimatological characteristics of evapotranspiration and soil water content in Hungary. Analysis is carried out using a modified version of the Thornthwaite model (THORNTHWAITE, 1948). Actual evapotranspiration is estimated as the product of Thornthwaite's potential evapotranspiration PET and the $\beta$ function of MiNTZ and WALKER (1993). A second order implicit numerical scheme is used to estimate soil water content. The goodness of the model is tested on a 21-year data series from the Agrometeorological Observatory in Debrecen.

The correlation between actual evapotranspiration (ET), soil water content (VK) and environmental factors is analyzed in detail.

The lowest annual VK values are obtained on sandy areas, irrespective of the areal distribution of the annual precipitation. The highest annual VK values are recorded on clayey areas, where the areal distribution of VK is determined by the areal distribution of annual precipitation, too. The dependence of the areal distribution of annual VK on the areal distribution of the annual precipitation increases going from the coarser to finer soil texture.

The areal distributions of annual ET and annual VK are very similar. In spring, autumn and winter ET is independent of the soil texture, but in summer it does depend on both soil texture and the areal distribution of precipitation.

Table 1 . Water capacity at the wilting point $\left(\mathrm{VK}_{\mathrm{h}}\right)$ and of field capacity $\left(\mathrm{VK}_{\mathrm{sz}}\right)$ for five soil texture categories. (1) Parameter. (2) Soil texture. (3) Sand. (4) Sandy loam. (5) Loam. (6) Clay loam. (7) Clay.

Table 2. Relationship between the evapotranspiration (ET) and soil water content (VK) and the precipitation and temperature for the soil textures occurring at 115 meteorological stations over the selected periods. (1) Period. From top to bottom: months from January to December. a) Year. (2) Soil texture. (3)-(7): See Table 1. A. Correlation between the evapotranspiration (ET) and the air temperature $(\mathrm{T})$, precipitation $(\mathrm{P})$ and actual soil water content (VK). B. Correlation between the soil water content (VK) and the air temperature $(\mathrm{T})$, precipitation $(\mathrm{P})$ and evapotranspiration $(\mathrm{ET})$. Note: -: none of the correlations was significant. Soil texture at the 115 meteorological stations was distributed as follows: sand: 16 ; sandy loam: 9; loam: 63 ; clay loam: 21 ; clay: $7 . \mathrm{R}^{2}=$ coefficient of determination.

Fig. 1. P-T diagrams for the 115 meteorological stations in Hungary. (Data refer to the period from 1901-1950). Horizontal axis: annual mean air temperature, ${ }^{\circ} \mathrm{C}$. Vertical axis: annual precipitation sum, $\mathrm{mm}$ year $^{-1}$.

Fig. 2. Long-term mean annual course of measured and simulated soil water content (VK) and their standard deviations. (Long-term mean and standard deviation values refer to the period from 1972-1992.) 
Fig. 3. Annual course of soil water content (A) and actual evapotranspiration (B) for the soil texture categories sand, sandy loam, loam, clay loam and clay.

Fig. 4. Territorial distribution of mean annual soil water content (VK) (A), evapotranspiration (ET) (B) and annual precipitation sum (P) (C) in Hungary.

Fig. 5. Territorial distribution of actual evapotranspiration (ET) (A) and air temperature (T) (B) in Hungary in March.

Fig. 6. Territorial distribution of actual evapotranspiration (ET) (A) and soil water content (VK) (B) in Hungary in June.

Fig. 7. Territorial distribution of actual evapotranspiration (ET) (A) and precipitation $(\mathrm{P})(\mathrm{B})$ in Hungary in September. 